\title{
Gender-specific ageing and non-Mendelian inheritance of oxidative damage in marine copepods
}

\author{
Laura Rodríguez-Graña ${ }^{1,2, *}$, Danilo Calliari ${ }^{1,2}$, Peter Tiselius ${ }^{1}$, \\ Benni Winding Hansen ${ }^{3}$, Helen Nilsson Sköld ${ }^{1}$ \\ ${ }^{1}$ Department of Marine Ecology, University of Gothenburg, Kristineberg 566, SE 450-34, Fiskebäckskil, Sweden \\ ${ }^{2}$ Facultad de Ciencias, Universidad de la República, Iguá 4225, CP 11400, Montevideo, Uruguay \\ ${ }^{3}$ Department of Environmental, Social and Spatial Change, Universitetsvej 1, Box 260, Building 16.1, 4000 Roskilde, Denmark
}

ABSTRACT: Ageing in the marine pelagic copepod Acartia tonsa results in decreased feeding and production rates associated with an increase in the accumulation of protein oxidative damage, as predicted by the oxidative stress hypothesis. In laboratory experiments, we estimated sex-specific ageing effects on feeding and oxidative damage and on egg production rates of adult females. We also determined maternal effects on offspring by measuring egg hatching success and oxidative damage of nauplii from mothers of different ages. Males manifested more oxidative damage with age than females, providing an alternative explanation for the shorter life span in males. Older females produced fewer offspring, and nauplii with higher protein oxidative damage, than younger females. This study forms an empirical basis to link ageing, life span, sex differences and maternal fitness in animals that also reflects natural copepod population dynamics. Individual ageing processes and the resulting age structure in the population modulate mortality risk, parental effects on offspring performance, reproductive investment, and pelagic energy fluxes.

KEY WORDS: Ingestion rate - Fertility pattern . Maternal effect · Oxidative damage - Acartia tonsa

\section{Resale or republication not permitted without} written consent of the publisher

\section{INTRODUCTION}

Ageing is the progressive decline in biological functions with advancing age, caused by insufficient damage repair and homeostasis. The accumulation of reactive oxygen species in cells, resulting from normal

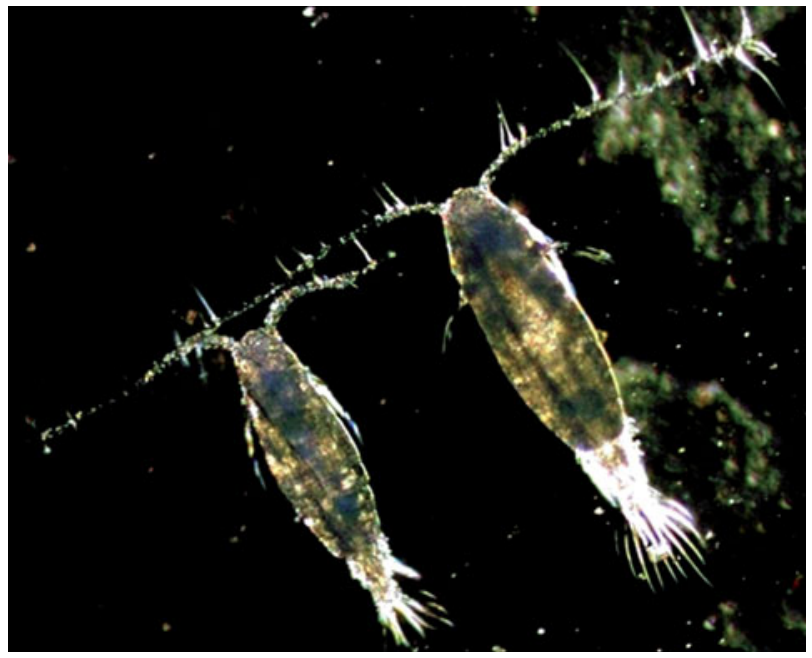

Acartia tonsa males (left) and females (right) change in appearance, physiology and behaviour as they age.

Photo: D. Calliari

metabolic processes and limited antioxidant defences, was proposed to play a causal role in ageing (Kregel \& Zhang 2007). Considerable research has focused on ageing in humans (Kirkwood 1999) and in model organisms such as roundworm, fruit fly, and laboratory rodents. Recent insights illustrate that ageing could also affect life-history traits in wild animals (Nussey et al. 2008, Ricklefs 2008). Inter-gender differences in longevity within species show that males have higher mortality rates and undergo faster ageing than females, suggesting that males invest relatively less in somatic maintenance and repair in favour of reproduc- 
tion (Bonduriansky et al. 2008). Age effects have also been reported for other traits. For instance, declining fecundity in ageing females is a common feature in several taxa (Novoseltsev et al. 2003a), including marine copepods (Carlotti et al. 1997). In turn, parental age can influence the quality of offspring produced by females in a range of organisms (Mousseau \& Dingle 1991, Hercus \& Hoffmann 2000, Giron \& Casas 2003). Assuming that oxidative stress has a significant role in ageing processes, attention has focused on developing anti-ageing therapies that enhance antioxidant defences through dietary supplementation. Among the compounds tested are polyunsaturated fatty acids and carotenoids (Esposito et al. 2002, Yehuda et al. 2002). In the marine environment, microalgae are the main source of both types of compounds (Volkman et al. 1989, Matsuno 2001). Most research effort to date has focused on elucidating the effects of algal quality in aquaculture (Wikfors \& Ohno 2001) and on the transfer of organic matter between producers and consumers (Müller-Navarra et al. 2000, Dalsgaard et al. 2003). However, no studies exist on the role of microalgae as potential anti-ageing agents in aquatic organisms.

Copepods are key organisms in marine ecosystems, where they contribute a major fraction of the secondary production. It is therefore of particular importance to understand factors constraining copepod dynamics and production (MZC2 2001). Population dynamics of marine copepods is ruled by variability in death rates, fecundity and growth, as well as restrictions in the rate of encounters among mates, and mating capability in males (Kiørboe 2006). Sex ratios of pelagic copepods are biased towards females (Parrish \& Wilson 1978). Male longevity is supposed to be constrained by faster development rates, smaller body sizes (Gilbert \& Williamson 1983) and more active swimming with consequent higher predation mortality than in females (Kiørboe \& Bagøien 2005, Kiørboe 2006). Also, males of Acartia hudsonica are more susceptible to toxins in algal diets (Avery et al. 2008), constituting a further process that could contribute to female-biased sex ratios in wild populations. However, no studies have investigated possible molecular and biochemical reasons behind the poorer somatic conditions in male, as compared to female copepods.

While inter-gender mortality and integrative physiological connections across the copepod life span are being studied (Kiørboe \& Bagøien 2005, Kiørboe 2006, Avery et al. 2008), ageing as an explicit life-history regulatory factor has been poorly tested in females (Carlotti et al. 1997) and information on male life span is rare (although see Parrish \& Wilson 1978, Avery et al. 2008). Variation in the fecundity of pelagic copepods in the field and under laboratory conditions has been accredited to changes in food availability, temperature (Ban 1994), food quality (Jónasdóttir et al. 1995) and salinity
(Devreker et al. 2009). A few studies have reported a progressive decline in copepod fecundity with time for females of known (Carlotti et al. 1997) or assumed age (Parrish \& Wilson 1978, Uye 1981). In wild populations, indirect estimations suggested that productivity may reflect an age-dependent physiological condition of adults (Diel \& Tande 1992, Durbin \& Durbin 1992).

Non-Mendelian maternal effects involve maternal nutrition via egg or pre- and post-natal supplies of food, and transmission of pathogens and antibodies (Bernardo 1996). Examples of nutritionally mediated maternal effects in copepods are egg size and offspring performance (e.g. growth, survival, motility; Ianora et al. 2004), but potential effects of maternal age per se have not been considered in this wide group of animals (but see Jamieson \& Santer 2003 for the egg-bearing copepod Cyclops kolensis). Negative maternal effects can be transmitted to offspring via cytoplasmic factors directly via maternal programming, or indirectly via offspring sensitivity to maternally transmitted factors, affecting the development and fitness of the progeny (Mousseau \& Fox 1998). The potential inheritance of age-related oxidative protein damage by offspring is, however, unknown.

In order to obtain an integrative understanding of organismal ageing and its potential consequences in population dynamics, we investigated age effects on feeding, reproductive investment and levels of oxidative damage in the pelagic copepod Acartia tonsa (Dana) subjected to food of different quality. A. tonsa is a widely distributed species which often dominates the mesozooplankton of estuaries and coastal waters. Due to its ecological significance, $A$. tonsa has been widely employed as a model organism in marine ecology research (e.g. Lance 1965, Kiørboe et al. 1985, Tiselius 1992, Mauchline 1998).

We hypothesized that senescence implies a reduction in the feeding and egg production rates in Acartia tonsa associated with an increase in the accumulation of protein oxidative damage as predicted by the oxidative stress hypothesis. Oxidative damage was also expected to be higher in males, thereby providing an alternative explanation for their shorter life span. Potential inheritance of age-related oxidative protein damage was assessed by quantifying such damage in offspring from mothers of different ages. We explored the same set of responses for 2 experimental copepod populations fed 2 algae of different biochemical composition to evaluate if food quality could also affect physiology and oxidative stress during ageing.

\section{MATERIALS AND METHODS}

Experimental setup. We kept a cohort of Acartia tonsa from egg until adult senescence and death (ca. 
$50 \mathrm{~d}$ ) in triplicate mesocosms for each food type, while controlling for food availability, temperature, salinity and photoperiod. We estimated feeding using ingestion and clearance rates, and reproductive investment using egg production rate, egg hatching success and nauplii production rate. We analysed the oxidative damage using the levels of protein carbonyls (Levine \& Stadtman 2001) in males and females at different ages and in the first naupliar stage spawned from mothers at different ages (Fig. 1).

Algal strains were provided by the algal culture collection, University of Gothenburg, and cultured at Kristineberg Marine Research Station (KMRS), in B1 medium at $18^{\circ} \mathrm{C}$ under a $14 \mathrm{~h}$ light:10 h dark regime, similar to springtime conditions in temperate regions. Cultures were kept and used as food in the exponential growth phase. Two algae of diverse biochemical quality (differing mainly in their fatty acid profiles)Rhodomonas sp. and Thalassiosira weissflogii-were selected, considering their extensive use as food in experimental marine ecology, their effects on somatic growth and fecundity in copepods and absence of any known substance that may affect long-term fecundity. The genus Rhodomonas (RHO, cryptophyte) produces higher somatic growth (Koski et al. 1998) and egg production rate (Broglio et al. 2003) than T. weissflogii (TW, diatom). In addition, cryptophytes have a higher percentage of docosahexaenoic acid than diatoms (Brown 2002) and high C:N ratios (Broglio et al. 2003). The fatty acid composition in our strains (RHO strain no. 9 and TW strain no. 91) differed in the presence and/or amount of some fatty acids (Table 1). TW has not been found to produce unsaturated aldehydes, as other diatoms do (Wichard et al. 2005), which can be toxic for adult copepods or their offspring (Ianora et al. 2004); the TW strain used here was previously found not to be toxic for Acartia clausi (Calliari \& Tiselius 2005).

Fatty acids. The fatty acid composition of the algae was determined on 4 replicates of $100 \mathrm{ml}$ algal cultures filtered onto GF/G filters. The filters were extracted for lipids by a chloroform:methanol mixture (2:1 v:v). An internal standard solution of heptadecanoic acid methyl ester in methanol was added to each vial. Samples were trans-esterified by acetyl chloride in methanol. The fatty acid methyl esters were analyzed by gas chromatography-mass spectrometry (Agilent 6890 series) equipped with a column Agilent DB23 (60 m, ID $250 \mu \mathrm{m}$, film thickness of $0.3 \mu \mathrm{m}$ ) using helium as a carrier gas at a constant flow rate of $1 \mathrm{ml}$ $\mathrm{min}^{-1}$. The oven temperature program was initially

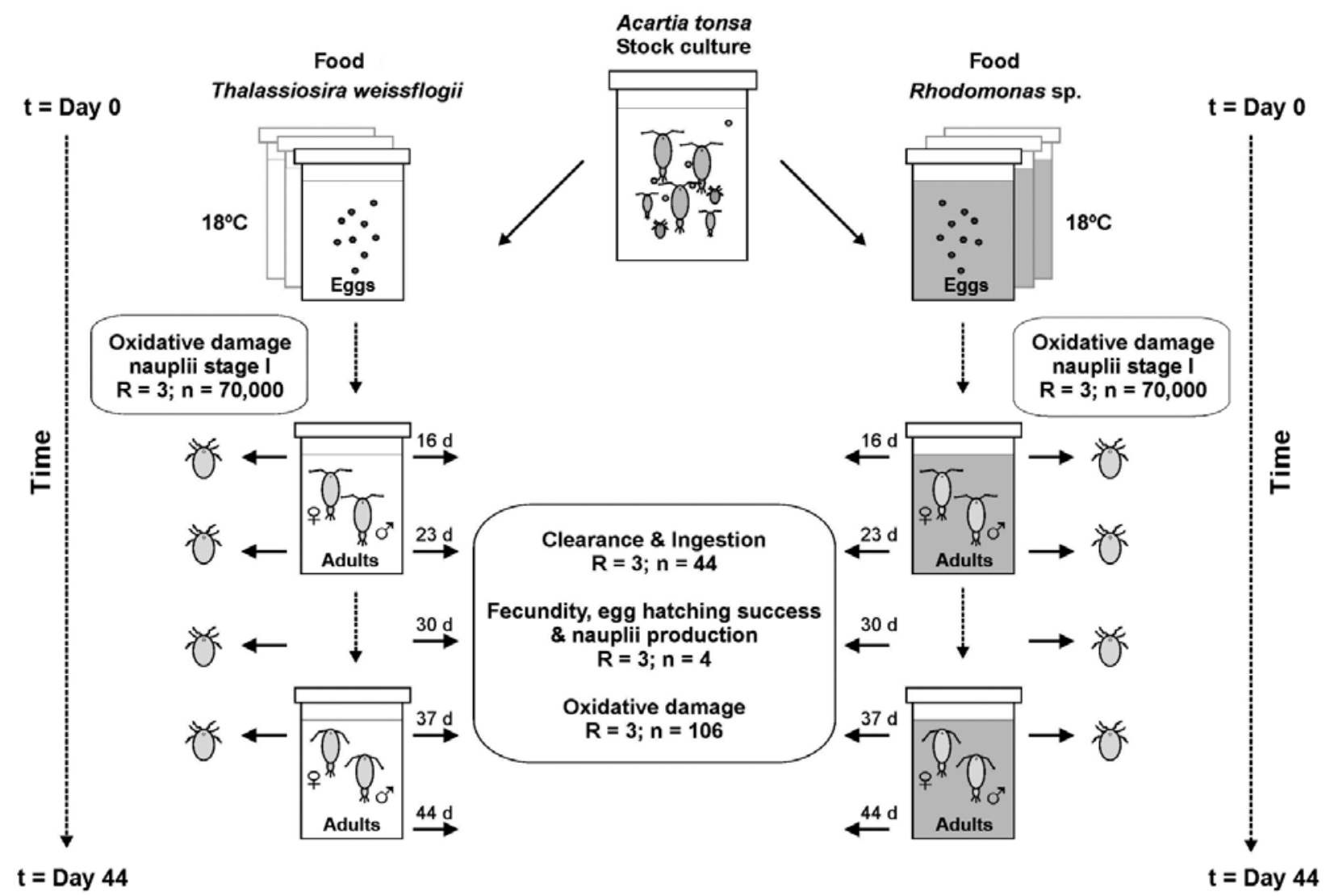

Fig. 1. Experimental design showing food, temperature conditions and variables estimated in males, females and nauplii of Acartia tonsa. R: number of replicates per treatment; $\mathrm{n}$ : number of individuals per replicate 
$60^{\circ} \mathrm{C}$ with a temperature ramp of $24.6^{\circ} \mathrm{C} \mathrm{min}^{-1}$ until $200^{\circ} \mathrm{C}$, which was maintained for $10 \mathrm{~min}$, followed by a second temperature ramp of $5^{\circ} \mathrm{C} \mathrm{min}^{-1}$ until $250^{\circ} \mathrm{C}$, which was maintained for $3 \mathrm{~min}$. The mass spectrometer was run in selective ion monitoring mode by application of the masses $\mathrm{m} / \mathrm{z}=55,74,79$ and 81 . The programmable temperature vaporization inlet was operated in splitless mode with the evaporation program going from 60 to $300^{\circ} \mathrm{C}$ with a temperature ramp of $720^{\circ} \mathrm{C} \mathrm{min}{ }^{-1}$ and maintained at $300^{\circ} \mathrm{C}$ for $2 \mathrm{~min}$.

Rearing. Acartia tonsa that originated in the Öresund, Denmark, were obtained from the Danish Technical University, Charlottenlund, and cultured at KMRS. Fresh A. tonsa eggs were placed in $30 \mathrm{l}$ tanks containing $0.3 \mu \mathrm{m}$ filtered Gullmar Fjord deep water ( salinity $=34$, ca. 18500 eggs $\operatorname{tank}^{-1}$ ) and kept at $18^{\circ} \mathrm{C}$ in a temperature-controlled room under constant low light conditions. Algal food was provided at a constant level of $500 \mu \mathrm{g} \mathrm{C} \mathrm{l}^{-1}$ (corresponding to 19427 and 4969 cells $\mathrm{ml}^{-1}$ for RHO and TW, respectively). Cell concentration in the copepod growing tanks was checked and

Table 1. Rhodomonas sp. and Thalassiosira weissflogii. Fatty acid composition of the algal diets during their exponential growth phase, as percent of the total mass of fatty acids. Data are weight percentage of total fatty acids (mean $\pm \mathrm{SD} \mathrm{n}=4$ )

\begin{tabular}{|lcc|}
\hline Fatty acid & $\begin{array}{c}\text { Rhodomonas sp. } \\
\text { (strain no. } 9 \text { ) }\end{array}$ & $\begin{array}{c}\text { T. weissflogii } \\
\text { (strain no. 91) }\end{array}$ \\
\hline C8:0 & $0.03 \pm 0.00$ & $0.08 \pm 0.01$ \\
C10:0 & $0.01 \pm 0.00$ & $0.01 \pm 0.00$ \\
C14:0 & $4.12 \pm 0.71$ & $4.36 \pm 1.86$ \\
C15:0 & $0.21 \pm 0.05$ & $1.30 \pm 0.21$ \\
C15:1 cis (n-5) & $0.01 \pm 0.00$ & $0.04 \pm 0.01$ \\
C16:0 & $11.73 \pm 2.38$ & $23.82 \pm 0.91$ \\
C16:1 cis(n-9) & $2.46 \pm 0.13$ & $20.78 \pm 3.45$ \\
C17:0 & $0.17 \pm 0.03$ & $0.59 \pm 0.02$ \\
C18:0 & $0.83 \pm 0.13$ & $0.91 \pm 0.03$ \\
C18:1 cis (n-9) & $3.11 \pm 0.03$ & $2.06 \pm 0.94$ \\
C18:2 trans (n-6) & 0 & $0.01 \pm 0.01$ \\
C18:2 cis (n-6) & $10.68 \pm 0.12$ & $0.45 \pm 0.06$ \\
C18:3 cis (n-6) & $1.60 \pm 0.28$ & $0.51 \pm 0.21$ \\
C18:3 cis (n-3) & $29.25 \pm 1.36$ & $0.06 \pm 0.01$ \\
C20:0 & $0.02 \pm 0.01$ & $0.13 \pm 0.00$ \\
C20:1 cis (n-9) & $0.02 \pm 0.01$ & 0 \\
C20:2 cis (n-6) & $0.04 \pm 0.00$ & 0 \\
C21:0 & 0 & $0.01 \pm 0.00$ \\
C20:3 cis(n-6) & $0.09 \pm 0.02$ & $0.14 \pm 0.06$ \\
C20:4 cis (n-6) & $1.25 \pm 0.34$ & $0.35 \pm 0.09$ \\
C20:3 cis (n-3) & $0.05 \pm 0.00$ & 0 \\
C22:0 & $0.02 \pm 0.01$ & $0.49 \pm 0.05$ \\
C20:5 cis (n-3) & $21.29 \pm 1.52$ & $33.44 \pm 5.55$ \\
C22:1 cis (n-9) & $0.04 \pm 0.02$ & $0.12 \pm 0.02$ \\
C22:2 cis (n-6) & $0.21 \pm 0.01$ & 0 \\
C24:0 & $0.08 \pm 0.02$ & $1.56 \pm 0.07$ \\
C24:1 cis (n-9) & 0 & $0.01 \pm 0.01$ \\
C22:6 cis (n-3) & $12.69 \pm 0.90$ & $8.80 \pm 1.40$ \\
\hline
\end{tabular}

adjusted daily to the desired $\mathrm{C}$ level. Cell concentration was measured with an Elzone 5380 particle analyser fitted with a $95 \mu \mathrm{m}$ orifice tube, and $\mathrm{C}$ content estimated from cell volume and a specific $\mathrm{C}$ content based on Mullin et al. (1966). The measurements of food concentration and food addition were performed at approximately the same time every day during the experiment.

Acartia tonsa nauplii Stage I do not feed, and Stages II and III are not able to ingest TW because of its size (16.6 $\mu \mathrm{m}$ equivalent spherical diameter, ESD; Berggreen et al. 1988, authors' pers. obs.). For that reason, nauplii Stages II to $\mathrm{V}$ in the TW treatment were fed RHO (6.9 $\mu \mathrm{m}$ ESD) (Fig. 2). We assumed that this would not affect the testing of the effect of food, since most of the biomass gained via individual growth occurs during and after the juvenile stage (copepodid $\mathrm{I}_{i}$ Berggreen et al. 1988).

In order to maintain an age-synchronised population, once copepods reached the adult stage on Day 16, and subsequently on Days 23, 30 and 37, all water in the growing tanks was gently filtered through a $200 \mu \mathrm{m}$ sieve, and only adults were collected and returned to the experimental tanks. Before returning adults to the tanks, the entire population was carefully examined in several batches under low magnification to make sure neither nauplii nor small copepodids were present. Because of individual variability in moulting, some individuals reached the adult stage earlier than others. We stress that such divergence does not affect the results of the present study. The age of the copepods was the main factor of analysis and strictly controlled along the experiment.

Response variables. For each algal treatment, clearance rate $\left(\mathrm{CR}, \mathrm{ml}\right.$ ind. $\left.^{-1} \mathrm{~d}^{-1}\right)$ and ingestion rate $(\mathrm{IR}$,

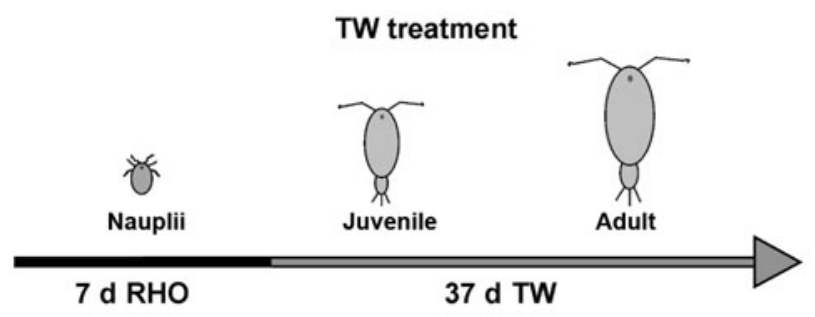

RHO treatment

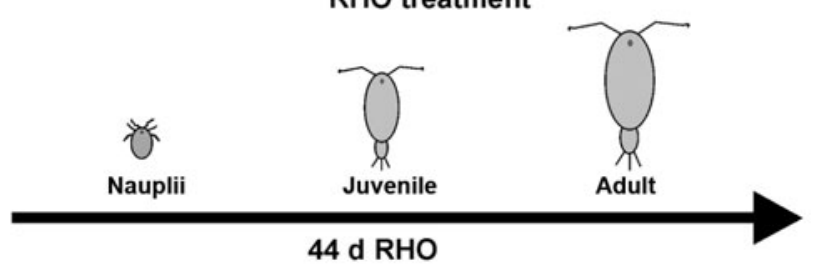

Fig. 2. Food treatments. RHO: Rhodomonas sp. (black); TW: Thalassiosira weissflogii (grey) 
$\mu \mathrm{g} \mathrm{C}$ ind $\mathrm{d}^{-1} \mathrm{~d}^{-1}$ ) were analysed separately by sex at Days 16, 23, 30 and 37, and on Day 44 for females only. Adult males and females $(41 \pm 10$ individuals $)$ were individually picked under a dissecting microscope and transferred to a $625 \mathrm{ml}$ borosilicate bottle for each replicate tank filled with the corresponding food from

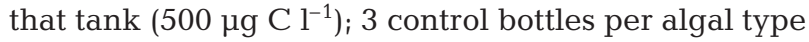
were prepared containing the same suspension at the same concentration but without copepods. Experimental and control bottles were incubated on a plankton wheel (0.2 rpm). After $24 \mathrm{~h}$, cell numbers were counted (Elzone analyser, $95 \mu \mathrm{m}$ orifice tube) and CR and IR were estimated in accordance with Frost (1972) as:

$$
\begin{aligned}
& \mathrm{CR}=\mathrm{V} /\left[\ln \left(\mathrm{C}_{\mathrm{C}} / \mathrm{C}_{\mathrm{exp}}\right) \times \mathrm{N} \times \mathrm{t}\right] \\
& \mathrm{IR}=\mathrm{CR} \times \mathrm{C}_{\mathrm{avg}}, \text { with } \mathrm{C}_{\mathrm{avg}}=\left(\mathrm{C}_{\text {end }}-\mathrm{C}_{0}\right) / \ln \left(\mathrm{C}_{\mathrm{end}} / \mathrm{C}_{0}\right)
\end{aligned}
$$

where $\mathrm{V}$ is the water volume in the bottles $(625 \mathrm{ml}$ when sealed), $\mathrm{C}_{\mathrm{c}}$ and $\mathrm{C}_{\exp }$ are the concentrations of cells in control and experimental bottles, respectively, $\mathrm{N}$ is the number of individuals per bottle and $\mathrm{t}$ is the incubation time $(1 \mathrm{~d})$. For $\mathrm{IR}, \mathrm{C}_{\text {end }}$ and $\mathrm{C}_{0}$ represent final and initial cell concentration in experimental bottles, respectively.

Egg production rates (EPR, eggs female $\left.{ }^{-1} \mathrm{~d}^{-1}\right)$, egg hatching success (EHS, \%) and nauplii production rates $\left(\mathrm{NPR}=\mathrm{EPR} \times \mathrm{EHS}\right.$, nauplii female $\left.\mathrm{f}^{-1} \mathrm{~d}^{-1}\right)$ were estimated for each replicate experimental tank at each age by incubating 3 to 5 females in standing $625 \mathrm{ml}$ bottles for $24 \mathrm{~h}$. Two pseudoreplicates, e.g. replicate bottles corresponding to the same experimental tank, were also considered and their values averaged to estimate the EPR, EHS and NPR for each replicate tank. Females from the growing tanks were individually picked under a low magnification microscope and transferred to bottles containing the corresponding algal suspension provided at $500 \mu \mathrm{g} \mathrm{C}^{-1}$. The selected females were checked for the presence of spermatophores produced during incubations were collected on a $50 \mu \mathrm{m}$ mesh sieve, counted, transferred to multiwell plates filled with filtered seawater and kept at $18^{\circ} \mathrm{C}$. The number of nauplii hatched was recorded after 24 and $48 \mathrm{~h}$, and EHS was calculated as the number of nauplii divided by the total number of eggs produced in each bottle.

To assess oxidative damage in adult copepods, 3 replicate samples for males and females (106 \pm 16 ind. from each growing tank) were collected at Days 16, 23, 30 and 37 (plus Day 44 for females only), quick-frozen in dry ice and stored at $-80^{\circ} \mathrm{C}$. To assess oxidative damage in nauplii Stage I, eggs were collected from each tank at Days 16, 23, 30 and 37, transferred to 81 buckets filled with filtered seawater and provided with gentle bubbling. After $24 \mathrm{~h}$, newly hatched nauplii were collected (ca. 70000 nauplii) and frozen at $-80^{\circ} \mathrm{C}$. Samples were homogenised in a RIPA lysis buffer
(Pierce) (Hernebring et al. 2006), debris was pelleted at $14000 \times g$ for $10 \mathrm{~min}$ at $4^{\circ} \mathrm{C}$ and supernatant was recovered. Protein concentration was measured in triplicate for each sample using the BCA Protein Assay Kit (Pierce) and the samples used for comparison were randomly derivatized at the same time using $7.5 \mu \mathrm{g}$ protein sample $\mathrm{s}^{-1}$. The membrane was post-stained to validate transfer. Protein oxidation was analysed by measuring the levels of dinitrophenylhydrazone derivates of protein carbonyls using the Oxyblot S7150 Kit (Chemicon International), precasted $12 \%$ Tris-HCl NuPage gels (Invitrogen) with 3-N-morpholino-2hydroxpropane sulfonic acid (MOPS) running buffer (Invitrogen) and Hybond-P membranes (GE Healthcare). The antibody labelling pattern was visualised using ECL plus (GE Healthcare) and a Geldoc 2000 using the Quantity One software for labelling intensity quantifications (Bio-Rad Laboratories). The electrophoresis analyses were repeated twice for each set of samples. To address a potential increase in protein carbonyls in females, the membranes were incubated for 2 instead of $1 \mathrm{~d}$ and developed for 600 instead of $400 \mathrm{~s}$. All reagents not further specified were from SigmaAldrich.

The sex ratio of adult individuals in the growing tanks was estimated in $100 \mathrm{ml}$ samples taken from each tank. Samples were taken as part of the routine monitoring of the experimental population every ca. $7 \mathrm{~d}$ and were preserved in Lugol's solution (1\%). Later, adult males and females were counted and sexed ( $\mathrm{n}=$ $24 \pm 4$ ind. per replicate) .

Data analysis. ANOVA was used to test for differences between treatments and all variances were tested for homogeneity by Levene's test. If significant heteroscedasticity was found, the variables were square root- or log-transformed. All tests were also done on untransformed values to control for spurious effects of transformation, but in no case did the transformation change the conclusions. Student-NewmanKeuls (SNK) tests were used for post hoc comparisons. The full ANOVA results are presented in tables where each analysis refers to the corresponding figure (see Tables 2-5). In order to perform quantitative analyses and establish statistical significance on levels of oxidative stress among treatments (age, sex and/or food), only those samples loaded within the same gel were compared. Since each gel allows for the loading of a maximum of 17 wells at the same time (16 samples plus a protein size standard), we compared statistically the oxidative damage between (1) males and (2) females, both on Days 16, 23, 30 and 37, as well as on Day 44 for females only, for each food treatment; males and females in both food treatments at (3) Day 16 (young adults) and (4) Day 37 (senescence); and (5) nauplii from mothers at Days 16, 27 and 37 for both food treatments. 


\section{RESULTS}

Qualitative observations regarding external appearance and behaviour of Acartia tonsa revealed the general features that most organisms exhibit with ageing: from smooth and unspoiled bodies and active behaviour in younger adults to altered body pigmentation and texture in older individuals. Old copepods had darker coloration (greyish and bluish) with algae or crusts attached, and displayed a more sluggish swimming with weaker escape responses. We also observed a decrease in the relative number of males in the tanks at the end of the study (Fig. 3).

\section{Effect of age, sex and food on feeding}

Females exhibited higher ingestion and clearance rates than males, and both sexes showed higher ingestion of TW than RHO, presumably due to more efficient retention (Berggreen et al. 1988) (Fig. 4). Feeding rates of TW declined with age in both males and females, but there was a slight increase in feeding rates on RHO from Day 16 to 23 and for females this was a significant difference. For males and females after Day 23 the feeding rates on RHO declined slightly, but not significantly (Table 2 ).

\section{Effect of age on fecundity and nauplii production}

EPR increased from Day 16 to 30 in both food treatments, reaching a maximum of $53 \pm 11$ eggs female f $^{-1}$ $\mathrm{d}^{-1}$ in RHO and $37 \pm 4$ eggs female ${ }^{-1} \mathrm{~d}^{-1}$ in TW treatments. EPR then declined almost regularly in RHO and was more variable in TW treatments (Fig. 5a). EPR was significantly lower in older females (Day 37 to 44), and RHO resulted in higher EPR than TW. EHS was also significantly lower in older females, but no effect of diet was found on EHS (Fig. 5b). The resulting NPR was consequently also significantly lower for offspring spawned from females 37 and 44 d old (Fig. 5c, Table 3).
Levels of oxidative damage in adults

Males 30 to $37 \mathrm{~d}$ old had significantly higher carbonylated protein content under both diets. In contrast, females did not show such increased carbonylated protein levels with age (Figs. 6 \& 7, Table 4). Further tests showed that for $16 \mathrm{~d}$ old adults, neither gender nor food affected levels of carbonylated proteins (Fig. 8a), but after $37 \mathrm{~d}$ adult males showed higher oxidative stress than females and RHO-fed males exhibited higher protein oxidative damage than those fed TW (Fig. 8b). A significant interaction (Sex $\times$ Food) suggested that the effect of food was different for males and females (Table 5).

\section{Maternal effect as levels of oxidative damage in nauplii}

A maternal effect on oxidative stress was detected as higher carbonylated protein content in first stage nauplii produced by older females (Fig. 5d). The first stage nauplii do not feed, and rely on maternally derived nutrition. Interestingly, the effect was also dependent on the diet of the mothers evidenced by a significant Food $\times$ Age interaction. Nauplii produced by TW-fed females displayed higher oxidative damage (Fig. 5d,e, Table 3).

\section{DISCUSSION}

Results on integrated ageing effects in Acartia tonsa showed that the senescence response involved all physiological processes analysed, impaired reproductive capacity and was detectable as damage at the molecular level. These findings have strong implications for the understanding of the biology and ecology of copepods, particularly the mechanisms behind femalebiased populations, and more generally with regard to the reproductive consequences and mechanisms of ageing. Of particular interest is the novel finding of protein carbonyls as a negative maternal effect.

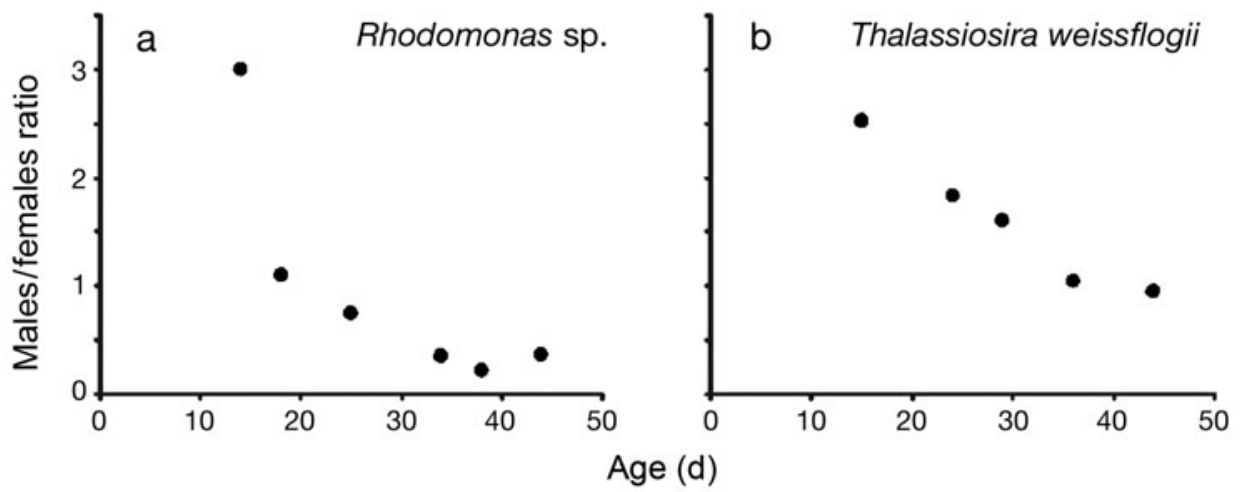

Fig. 3. Acartia tonsa. Sex ratio estimated as the proportion of A. tonsa males to females in the experimental tanks throughout the experiments for (a) Rhodomonas sp. and (b) Thalassiosira weissflogii treatments 

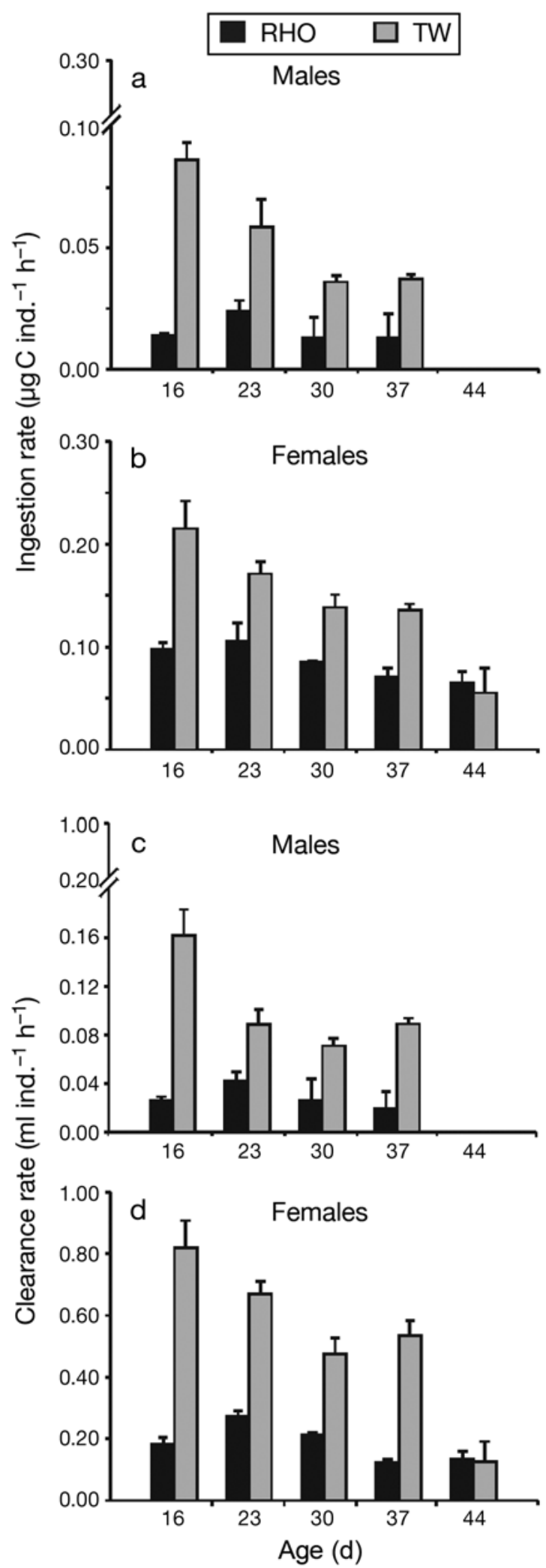

Fig. 4. Acartia tonsa. Ageing effects on feeding rates. Ingestion and clearance rates (mean $\pm \mathrm{SE} ; \mathrm{n}=3)$ in $(\mathrm{a}, \mathrm{c})$ males and (b,d) females fed Rhodomonas sp. (RHO) and Thalassiosira weissflogii (TW)
Table 2. ANOVA comparison of ingestion and clearance rates in Acartia tonsa males and females (factor: Sex) at different ages (factor: Age) offered Rhodomonas sp. (RHO) or Thalassiosira weissflogii (TW) as food (factor: Food). All 2-factor ANOVAs testing the effect of both food and age showed significant interactions and therefore each diet was tested separately using 1-way ANOVA

\begin{tabular}{|lccccc}
\hline Source & $\mathrm{SS}$ & $\mathrm{df}$ & $\mathrm{MS}$ & $F$ & $\mathrm{p}$ \\
\hline \multicolumn{5}{l}{ Ingestion rate, } \\
Sex & 0.265 & 1 & 0.265 & 69.6 & 0.000 \\
Food & 0.124 & 1 & 0.124 & 32.6 & 0.000 \\
Sex $\times$ Food & 0.000224 & 1 & 0.000224 & 0.0587 & 0.810 \\
Error & 0.187 & 49 & 0.00381 & & \\
Total & 4.15 & 53 & & & \\
\multicolumn{7}{l}{ Clearance rate, data log-transformed (Fig. } \\
Sex & 6.654 & 1 & 6.65 & 82.1 & 0.000 \\
Food & 3.244 & 1 & 3.24 & 40 & 0.000 \\
Sex $\times$ Food & 0.086 & 1 & 0.0858 & 1.06 & 0.309 \\
Error & 3.972 & 49 & 0.0811 & & \\
Total & 56.2 & 53 & & & \\
\end{tabular}

Ingestion rate in males, data square root-transformed (Fig. 4a) RHO

$\begin{array}{lccccc}\text { Age } & 0.00546 & 3 & 0.00182 & 1.11 & 0.408 \\ \text { Error } & 0.0115 & 7 & 0.00164 & & \\ \text { Total } & 0.194 & 11 & & & \\ \text { TW } & & & & & \\ \text { Age } & 0.0215 & 3 & 0.00717 & 12.6 & 0.002 \\ \text { Error } & 0.00456 & 8 & 0.000570 & & \\ \text { Total } & 0.655 & 12 & & & \\ & \text { SNK post hoc: } 30=37=23<16 & \end{array}$

Ingestion rate in females, data square root-transformed (Fig. 4b) RHO

$\begin{array}{lccccc}\text { Age } & 0.0131 & 4 & 0.00328 & 3.38 & 0.054 \\ \text { Error } & 0.00969 & 10 & 0.000969 & & \\ \text { Total } & 1.149 & 20 & & & \\ \text { TW } & & & & & \\ \text { Age } & 0.0961 & 4 & 0.0240 & 9.63 & 0.002 \\ \text { Error } & 0.0249 & 10 & 0.00249 & & \\ \text { Total } & 2.148 & 20 & & & \\ & \text { SNK post hoc: } 44<37=30=23=16 & \end{array}$

Clearance rate in males (Fig. 4c)

$\mathrm{RHO}$

$\begin{array}{lccccc}\text { Age } & 0.000849 & 3 & 0.000283 & 0.630 & 0.616 \\ \text { Error } & 0.00360 & 8 & 0.000450 & & \\ \text { Total } & 0.0137 & 10 & & & \\ \text { TW } & & & & & \\ \text { Age } & 0.0147 & 3 & 0.0049 & 9.97 & 0.004 \\ \text { Error } & 0.00393 & 8 & 0.000492 & & \\ \text { Total } & 0.145 & 12 & & & \\ & \text { SNK post hoc: } 30=23=37<16 & \end{array}$

Clearance rate in females, data log-transformed (Fig. 4d)

RHO

$\begin{array}{lccccc}\text { Age } & 0.365 & 4 & 0.0911 & 15.35 & 0.000 \\ \text { Error } & 0.0594 & 10 & 0.00594 & & \\ \text { Total } & 10.038 & 15 & & & \end{array}$

Total

SNK post hoc: $16=37=44<30=23$

TW

Age

Error

Total

$\begin{array}{ccccc}1.72 & 4 & 0.430 & 9.949 & 0.002 \\ 0.432 & 10 & 0.0432 & & \\ 4.346 & 15 & & & \end{array}$

SNK post hoc: $44<30=37=23=16$ 

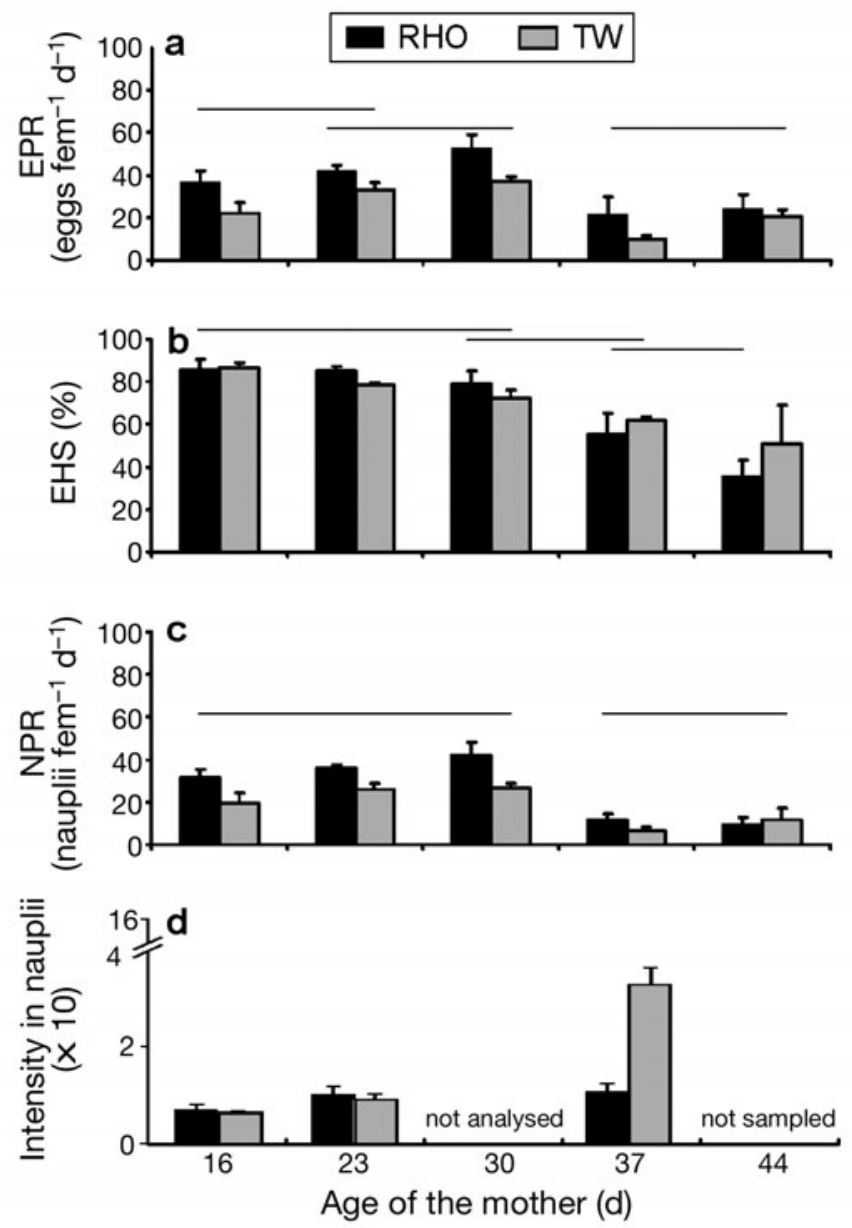

e Protein oxidation in nauplii

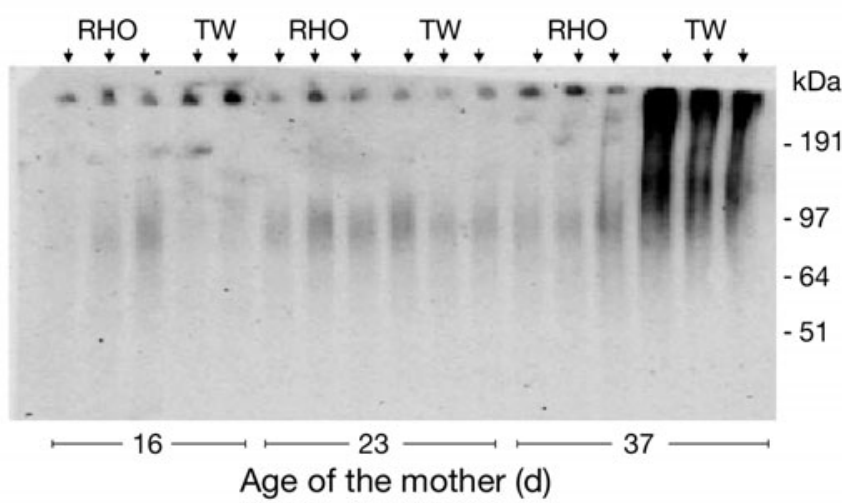

Fig. 5. Acartia tonsa. Fecundity and maternal effect. Estimations were made on females at Days 16, 23, 30, 37 and 44 fed Rhodomonas sp. (RHO) or Thalassiosira weissflogii (TW). (a) Egg production rate (EPR), (b) egg hatching success (EHS), (c) nauplii production rate (NPR) and (d) carbonylated protein content of nauplii Stage I spawned by females. Data are mean $\pm \mathrm{SE} ; \mathrm{n}=3$. Solid lines represent homogeneous subsets according to the Student-Neuman-Keuls test. (e) Western blot demonstrating that nauplii spawned by $37 \mathrm{~d}$ old females fed TW exhibited the highest oxidative protein damage
Table 3. ANOVA comparison of egg production, egg hatching success and naupliar production of Acartia tonsa females of a different age (factor: Age), and carbonylated protein content in nauplii produced by females of different age (factor: Age; data log-transformed) offered Rhodomonas sp. (RHO) or Thalassiosira weissflogii (TW) as food (factor: Food)

\begin{tabular}{|c|c|c|c|c|c|}
\hline Source & SS & df & MS & $F$ & $\mathrm{p}$ \\
\hline \multicolumn{6}{|c|}{ Egg production (Fig. 5a) } \\
\hline Food & 919 & 1 & 919 & 19.4 & 0.000 \\
\hline Age & 3223 & 4 & 806 & 17.0 & 0.000 \\
\hline Food $\times$ Age & 143 & 4 & 35.8 & 0.76 & 0.565 \\
\hline Error & 946 & 20 & 47.3 & & \\
\hline Total & 32368 & 30 & & & \\
\hline \multirow{2}{*}{\multicolumn{6}{|c|}{$\begin{array}{l}\text { SNK post hoc: } \\
37=44,44=16,16=23,23=30,37<16<30,44<23\end{array}$}} \\
\hline & & & & & \\
\hline \multicolumn{6}{|c|}{ Egg hatching success (Fig. 5b) } \\
\hline Food & 31.8 & 1 & 31.8 & 0.134 & 0.718 \\
\hline Age & 7739 & 4 & 1935 & 8.14 & 0.000 \\
\hline Food $\times$ Age & 538 & 4 & 135 & 0.566 & 0.690 \\
\hline Error & 4753 & 20 & 238 & & \\
\hline Total & 155862 & 30 & & & \\
\hline \multirow{2}{*}{\multicolumn{6}{|c|}{$\begin{array}{l}\text { SNK post hoc: } \\
44=37,37=30,30=23=16,44<30,37<23=16\end{array}$}} \\
\hline & & & & & \\
\hline \multicolumn{6}{|c|}{ Naupliar production (Fig. 5c) } \\
\hline Food & 482 & 1 & 482 & 10.6 & 0.004 \\
\hline Age & 3294 & 4 & 823 & 18.2 & 0.000 \\
\hline Food $\times$ Age & 281 & 4 & 70.2 & 1.55 & 0.227 \\
\hline Error & 907 & 20 & 45.3 & & \\
\hline Total & 19478 & 30 & & & \\
\hline \multicolumn{6}{|c|}{ SNK post hoc: $37=44<16=23=30$} \\
\hline \multicolumn{6}{|c|}{ Carbonylated protein content (Fig. 5d) } \\
\hline Food & 0.0684 & 1 & 0.0684 & 6.49 & 0.027 \\
\hline Age & 0.548 & 2 & 0.274 & 26.0 & 0.000 \\
\hline Food $\times$ Age & 0.267 & 2 & 0.133 & 12.7 & 0.001 \\
\hline Error & 0.116 & 11 & 0.0105 & & \\
\hline Total & 281.0 & 17 & & & \\
\hline \multicolumn{6}{|c|}{ SNK post hoc: $16<23<37$} \\
\hline
\end{tabular}

Decreased foraging with age has been recorded mainly for mammals (Morley 2001) and birds (Catry et al. 2006). In humans, decreased food intake with age (known as anorexia of ageing; Morley \& Silver 1988) is related to lower metabolic rates and failure to develop sensory-specific signals associated with the satiety system (Morley 2001). With respect to copepods, an early study indicated progressively decreased feeding rates with time for wild individuals of unknown age of Eucalanus subcrassus, Tortanus gracilis, Calanopia elliptica and Paracalanus aculeatus (Ikeda 1977). A progressive decline with age in faecal pellet production by Centropages typicus females (Carlotti et al. 1997) also likely results from diminished ingestion rates in older individuals. To our knowledge, the present study is the first rigorous report of age-related feeding declines in copepods. Omnivorous copepods are capable of discriminatory feeding using mechanoand chemosensory mechanisms (Teegarden 1999), but the effect of age on tactile or chemosensory recognition or changes in palatability requires further investigation. Such effects of ageing may involve not only 


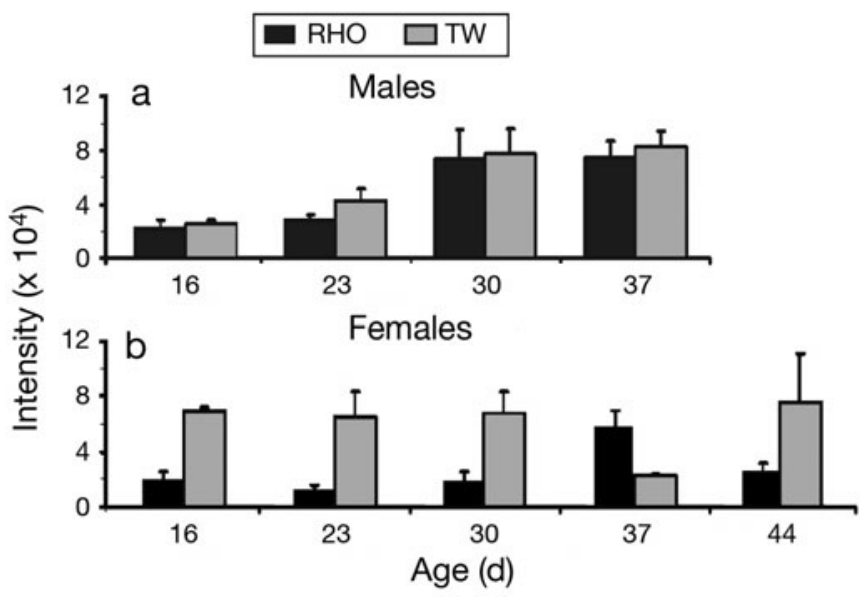

Fig. 6. Acartia tonsa. Oxidative protein damage. Carbonylated protein content of (a) males and (b) females fed Rhodomonas sp. (RHO, $\mathrm{n}=12$ ) or Thalassiosira weissflogii (TW, $\mathrm{n}=$ 11). Data are mean $\pm \mathrm{SE}_{;} \mathrm{n}=3$. Data for RHO and TW were obtained from different gels, so direct comparison between food treatments is not possible; for further details see text

Table 4. ANOVA comparison of carbonylated protein content in Acartia tonsa at different ages (factor: Age) offered Rhodomonas sp. (RHO) or Thalassiosira weissflogii (TW) as food; data log-transformed

\begin{tabular}{|c|c|c|c|c|c|}
\hline Source & $\mathrm{SS}$ & df & MS & $F$ & $\mathrm{p}$ \\
\hline \multicolumn{6}{|c|}{ Males (Fig. 6a) } \\
\hline \multicolumn{6}{|l|}{ RHO } \\
\hline Age & 0.690 & 3 & 0.23 & \multirow[t]{3}{*}{7.91} & \multirow[t]{4}{*}{0.009} \\
\hline Error & 0.233 & 8 & 0.0291 & & \\
\hline \multirow[t]{2}{*}{ Total } & 256.0 & 12 & & & \\
\hline & \multirow{2}{*}{\multicolumn{5}{|c|}{ SNK post hoc: $16=23<30=37$}} \\
\hline 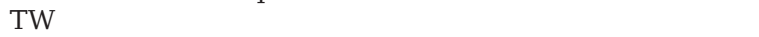 & & & & & \\
\hline Age & 0.419 & 3 & 0.140 & \multirow[t]{3}{*}{5.54} & \multirow[t]{4}{*}{0.029} \\
\hline Error & 0.177 & 7 & 0.0252 & & \\
\hline \multirow[t]{2}{*}{ Total } & 245.3 & 11 & & & \\
\hline & \multicolumn{4}{|c|}{ SNK post hoc: $16=23,23=30=37,16<30$} & \\
\hline \multicolumn{6}{|c|}{ Females (Fig. 6b) } \\
\hline \multicolumn{6}{|c|}{ RHO } \\
\hline Age & 0.805 & 4 & 0.201 & \multirow{3}{*}{3.25} & \multirow[t]{3}{*}{0.059} \\
\hline Error & 0.619 & 10 & 0.0619 & & \\
\hline Total & 281 & 15 & & & \\
\hline \multicolumn{6}{|l|}{ TW } \\
\hline Age & 0.489 & 4 & 0.122 & \multirow[t]{3}{*}{3.23} & \multirow[t]{3}{*}{0.060} \\
\hline Error & 0.379 & 10 & 0.0379 & & \\
\hline Total & 334 & 15 & & & \\
\hline
\end{tabular}

decreased food consumption with age but also qualitative changes in the diet through altered selectivity.

Decreased fertility with age has been reported for diverse organisms such as rotifers (Snell \& Childress 1987), coleopters (Fox 1993) and fruit flies (Müller et al. 2001). Such a response may imply an evolutionary adaptation to a short life span (Medawar 1952, Stearns et al. 2000). Here, EPR in Acartia tonsa were highest at Days 23 to 30 and declined afterwards (Fig. 5). Maxi-
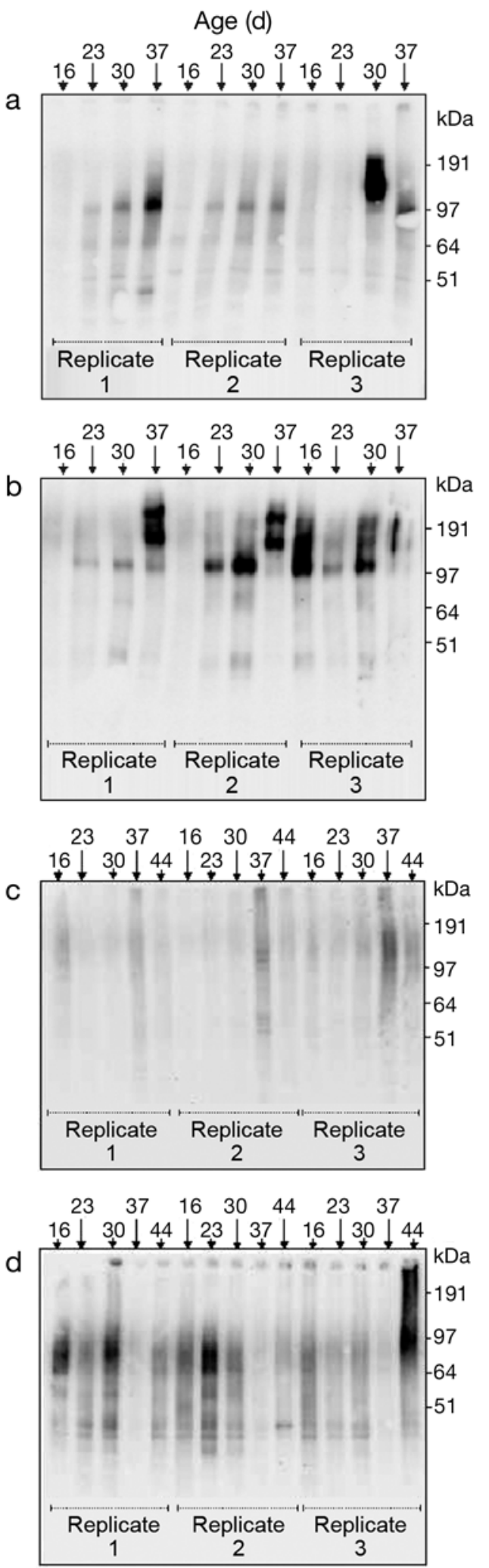

Fig. 7. Acartia tonsa. Oxidative protein damage. Western blot for $(\mathrm{a}, \mathrm{b})$ males and $(\mathrm{c}, \mathrm{d})$ females fed $(\mathrm{a}, \mathrm{c})$ Rhodomonas sp. or (b,d) Thalassiosira weissflogii. In (b) Replicate 3 for Day 16 appears abnormal and was excluded from analysis 


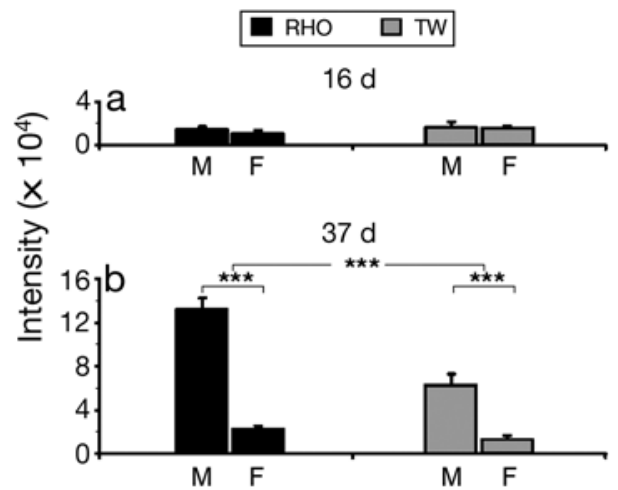

Fig. 8. Acartia tonsa. Oxidative protein damage. Carbonylated protein content of $A$. tonsa adult males (M) and females (F) fed Rhodomonas sp. (RHO) or Thalassiosira weissflogii (TW) at (a) Day $16(\mathrm{n}=11)$ and (b) Day $37(\mathrm{n}=$ 12). Values obtained as in Fig. $7 \mathrm{~b}$ estimated from 3 replicates. Western blot for adults at (c) Day 16 and (d) Day 37. Error bars are SE. Replicate \#3 in (c) for males $16 \mathrm{~d}$ old in the TW treatment appears abnormal and was excluded from further analysis

mum EPR around the middle of the female's life seems to be a common pattern for fruit flies (Novoseltsev et al. 2003b) and copepods, as shown for Centropages typicus (Carlotti et al. 1997) and Eurytemora affinis (under the combined effect of temperature and salinity; Devreker et al. 2009). The mechanism behind that pattern has been alternately explained in terms of energy loss during the last moulting from copepodid Stage V to adult when oocytes mature (Fryd et al. 1991) or the time required to complete vitellogenesis (Plourde \& Runge 1993).

Table 5. ANOVA comparison of carbonylated protein content in 16 and $37 \mathrm{~d}$ old Acartia tonsa males and females (factor: Sex) offered Rhodomonas sp. (RHO) or Thalassiosira weissflogii (TW) as food (factor: Food)

\begin{tabular}{|c|c|c|c|c|c|}
\hline Source & SS & $\mathrm{df}$ & MS & $F$ & $\mathrm{p}$ \\
\hline \multicolumn{6}{|c|}{ Age: 16 d (Fig. 8a) } \\
\hline Sex & 1344833 & 1 & 1344833 & 0.0294 & 0.868 \\
\hline Food & 681742 & 1 & 681742 & 0.0149 & 0.906 \\
\hline Sex $\times$ Food & 51862065 & 1 & 51862065 & 1.13 & 0.318 \\
\hline Error & 365965991 & 8 & 45745749 & & \\
\hline Total & 2340209867 & 12 & & & \\
\hline \multicolumn{6}{|c|}{ Age: 37 d (Fig. 8b) } \\
\hline Sex & 18881715405 & 1 & 18881715405 & 112 & 0.000 \\
\hline Food & 4599725724 & 1 & 4599725724 & 27.3 & 0.001 \\
\hline Sex $\times$ Food & 2606130575 & 1 & 2606130575 & 15.4 & 0.004 \\
\hline Error & 1350231499 & 8 & 168778937.4 & & \\
\hline Total & 67872371704 & 12 & & & \\
\hline
\end{tabular}

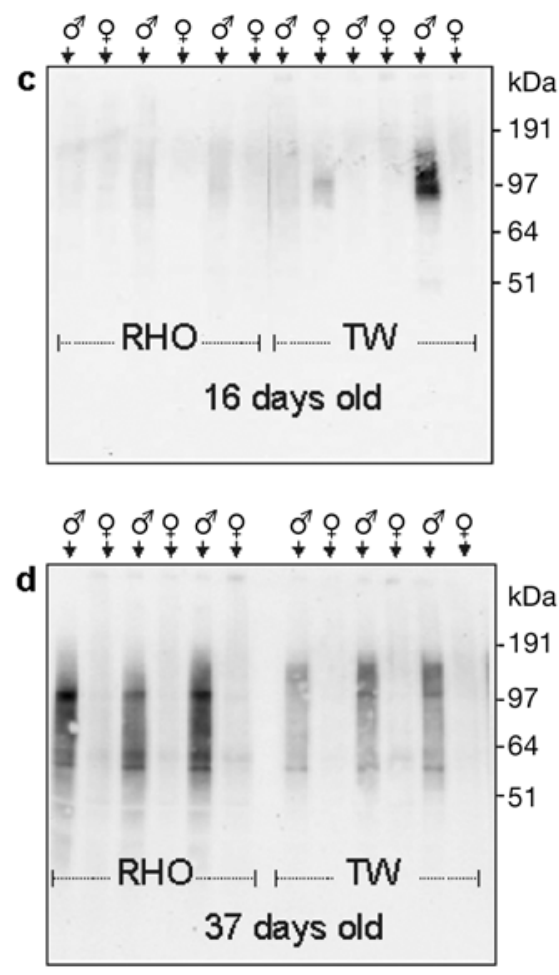

The results from the present study also indicate a strong decrease in reproductive output with age, due to combined declines in EPR and EHS. So far, variation in EPR in copepods has been attributed mainly to food availability (Ban 1994) and quality (Jónasdóttir et al. 1995, Ianora et al. 2004), as well as temperature (Ban 1994). Our results show decreased reproductive output as a direct consequence of the ageing process. Algae used in the present study do not impair reproduction, as they have been tested several times with positive results (particularly the diatom Thalassiosira weissflogii; Calliari \& Tiselius 2005, Calliari et al. 2006, present study). Food concentration (500 $\mu \mathrm{g} \mathrm{C} \mathrm{l}^{-1}$ ) was high but within realistic limits representative of eutrophic environments inhabited by Acartia tonsa. Furthermore, considering that food levels were close to saturation for $A$. tonsa (Berggreen et al. 1988), gamete production during this experiment was not energetically limited. Decreased EHS may be linked to higher content of oxidative products in eggs released by older females. Such nonMendelian inheritance of oxidative damage constitutes novel evidence for copepods (see below). During the experiment, females had continuous access to males so we assume that mating was not likely a limiting factor. However, we cannot rule out the possibility that sperm limitation also contributed to decreased EHS and NPR if sperm quality or mating ability decreased during senescence. That would reflect an effect of ageing acting through a different mechanism that deserves further at- 
tention in future studies. The present results on decreased reproductive output linked to ageing are of significance for the current understanding of field population dynamics and production, since realized fecundity (e.g. NPR), recruitment and demographic dynamics in field populations will likely be age-structured.

Age-related oxidative modifications to intracellular macromolecules (e.g. cytoskeletal proteins, enzymes and protein-signal mediators) have been reported in a diverse range of taxa (Kregel \& Zhang 2007). The accumulation of oxidatively modified proteins in the body is a sign of impaired protein turnover, and of failure of the mechanisms involved in their replacement (Friguet 2006). Copepods also accumulate oxidized proteins with age and exhibited sex-specific differences in oxidative damage levels. Why do Acartia tonsa males accumulate more oxidative damage than females? Our results suggest that the high female biomass turnover implied by offspring production may be a main factor. Protein turnover is one major path by which functional proteins are maintained and damaged proteins removed (Ryazanov \& Nefsky 2002). For A. tonsa females, the production of 36 to 50 eggs $\mathrm{d}^{-1}$ represents a daily turnover rate between 37 and $50 \%$ of their body mass. Males of this species can produce ca. 4 spermatophores $\mathrm{d}^{-1}$, representing only ca. $2 \%$ of their body mass (Mauchline 1998). Biomass turnover that includes the transfer of oxidized proteins to reproductive structures is thus a mechanism that may limit accumulation of oxidized products in females, but not males. An alternative explanation behind longer life span in females and low accumulated oxidative protein damage could be antioxidative properties of protein vitellogenin produced by females, as recently suggested in a study on bees (Seehuus et al. 2006). Nevertheless, copepod females also aged, which supports the idea that ageing is caused by multiple factors of which oxidative damage is only one component (Kirkwood \& Austad 2000).

Offspring performance-e.g. developing time, body size and survivorship-decreases with increasing maternal age in the univoltine freshwater copepod $C y$ clops kolensis (Jamieson \& Santer 2003). Such a maternal age effect was attributed to depletion of resources in older females. Similar conclusions were drawn for insects (Fox \& Dingle 1994, Giron \& Casas 2003). The present study combined maternal age, quality of food and maternal fitness, here measured as lower hatching success and higher carbonylated protein content in first stage nauplii produced by older females fed TW. These novel findings are of relevance not only for copepods but also with regard to all sexually reproducing species. Incorporation of oxidized proteins into eggs, as discussed above, constitutes an alternative hypothesis to explain the observed lower offspring quality produced by older females. A nutritional deficit in TW-fed fe- males could have decreased their antioxidant defences in the long term and resulted in a transfer of more carbonylated proteins to offspring at the end of their life.

Food affected oxidative levels among and within sexes (only for males) and in offspring. Contrary to our assumption, males fed TW showed lesser oxidative damage than those fed RHO. While there is no clear mechanism to explain that particular result, e.g. in fatty acid profiles, it strongly suggests the presence of differences in the nutritional and/or metabolic requirements among sexes in Acartia tonsa. This is consistent with recent results that demonstrate differential resistance between sexes to algal toxins in A. tonsa that lead to higher mortality rates in males (Avery et al. 2008).

\section{CONCLUSIONS}

One implication of the present findings is that mortality rates increase with age, and that such an increase should be higher for males than females. An early study had indeed suggested that pattern (Parrish \& Wilson 1978), and the decrease in the abundance of males in our tanks by the end of the present study supports that hypothesis. Our results suggest that copepod ageing resulting in a female-biased mesocosm population and non-Mendelian inheritance of protein damage may partly explain the cyclic population dynamics and female-biased sex ratios seen in nature, by passing on damage to offspring. Severe shortage of males has been linked to the fact that most females may never be fertilized in the field, and thus the population becomes fertilization limited (Kiørboe 2006). Our results were based on living conditions of copepods in the laboratory in the absence of predators. However, while predation has been suggested as one of the main sources of mortality in the field (Ohman \& Wood 1996, Hirst \& Kiørboe 2002), the degree of vulnerability to predators seems likely to vary with age (Williams \& Day 2003, Monaghan et al. 2008). New evidence also shows that non-consumptive mortality could also be important in causing copepod mortality (Tang et al. 2006).

These results offer new insights into both plankton ecology and ageing research with novel and integrative evidence on the effects of ageing on copepods at physiological and molecular levels. Maternal effects associated with ageing should be considered in future models of foraging, production, behaviour, reproduction and energetic investment, and particularly in population dynamics and evolutionary biology. Results from the present study also highlight the significance of explicitly considering age in the design of experimental studies, as well the need to extrapolate laboratory results on biological rates and behavioural responses to wild, age-structured populations. 
Acknowledgements. We thank E. Nilsson (Royal Swedish Academy of Sciences) for excellent technical assistance, M. Appelgren (Department of Marine Ecology, University of Gothenburg) for providing algal strains and V. Bravo (LinneoPalme Fellow) for technical assistance with copepods. T. Kiørboe (Technical University of Denmark), G. Roos (Institute for Medical Sciences, Umeå), T. Nyström (Gothenburg University) and 4 anonymous reviewers provided insightful and valuable comments on early versions of the manuscript. L.R.G. and D.C. were supported by Marie Curie Incoming International Fellowships (EU Commission FP-6; MIF1-CT2006-039884 and MIF1-CT-2006-021529), H.N.S. by Swedish Natural Science Council, Natural and Engineering (VR-NT) and B.W.H. by Danish National Research Council (grant no. 272-07-0485). This work conforms to the legal requirements of Sweden, where it was carried out.

\section{LITERATURE CITED}

Avery DE, Atland KK, Dam HG (2008) Sex-related differential mortality of a marine copepod exposed to a toxic dinoflagellate. Limnol Oceanogr 53:2627-2635

Ban S (1994) Effect of temperature and food concentration on post-embryonic development, egg production and adult body size of calanoid copepod Eurytemora affinis. J Plankton Res 16:721-735

Berggreen U, Hansen B, Kiørboe T (1988) Food size spectra, ingestion and growth of the copepod Acartia tonsa during development: implications for determination of copepod production. Mar Biol 99:341-352

Bernardo J (1996) Maternal effects in animal ecology. Am Zool 36:83-105

Bonduriansky R, Maklakov A, Zajitschek F, Brooks R (2008) Sexual selection, sexual conflict and the evolution of ageing and life span. Funct Ecol 22:443-453

Broglio E, Jónasdóttir SH, Calbet A, Jakobsen HH, Saiz E (2003) Effect of heterotrophic versus autotrophic food on feeding and reproduction of the calanoid copepod Acartia tonsa: relationship with prey fatty acid composition. Aquat Microb Ecol 31:267-278

Brown MR (2002) Nutritional value of microalgae for aquaculture. In: Cruz-Suárez LE, Ricque-Marie D, Tapia-Salazar M, Gaxiola-Cortés MG, Simoes N (eds) Avances en nutrición acuícola VI, Memorias del VI Simposium Internacional de Nutrición Acuícola, 3-6 Sep 2002, Cancún

Calliari D, Tiselius P (2005) Feeding and reproduction in a small calanoid copepod: Acartia clausi can compensate quality with quantity. Mar Ecol Prog Ser 298:241-250

Calliari D, Andersen MC, Thor P, Gorokhova E, Tiselius P (2006) Salinity modulates the energy balance and reproductive success of co-occurring copepods Acartia tonsa and A. clausi in different ways. Mar Ecol Prog Ser 312: $177-188$

> Carlotti F, Rey C, Javanshir A, Nival S (1997) Laboratory studies on egg and faecal pellet production of Centropages typicus: effect of age, effect of temperature, individual variability. J Plankton Res 19:1143-1165

Catry P, Phillips RA, Phalan B, Croxall JP (2006) Senescence effects in an extremely long-lived bird: the grey-headed albatross Thalassarche chrysostoma. Proc Biol Sci 273: 1625-1630

Dalsgaard J, St. John M, Kattner G, Müller-Navarra D, Hagen W (2003) Fatty acid trophic markers in the pelagic marine environment: a review. Adv Mar Biol 46:227-340

$>$ Devreker D, Souissi S, Winkler G, Forget-Leray J, Leboulenger F (2009) Effects of salinity, temperature and indi- vidual variability on the reproduction of Eurytemora affinis (Copepoda; Calanoida) from the Seine estuary: a laboratory study. J Exp Mar Biol Ecol 368:113-123

> Diel S, Tande K (1992) Does spawning of Calanus finmarchicus in high latitudes follow a reproducible pattern? Mar Biol 113:21-31

Durbin AG, Durbin EG (1992) Seasonal changes in size frequency distribution and estimated age in marine copepod Acartia hudsonica during a winter-spring diatom bloom in Narragansett Bay. Limnol Oceanogr 37:379-392

> Esposito E, Rotilio D, Di Matteo V, Di Giulio C, Cacchio M, Algeri S (2002) A review of specific dietary antioxidants and the effects of biochemical mechanisms related to neurodegenerative processes. Neurobiol Aging 23: $719-735$

$>$ Fox CW (1993) The influence of maternal age and mating frequency on egg size and offspring performance in Callosobruchus maculates (Coleptera: Bruchidae). Oecologia 96: 139-146

> Fox CW, Dingle H (1994) Dietary mediation of maternal age effects on offspring performance in a seed beetle (Coleoptera: Bruchidae). Funct Ecol 8:600-606

$>$ Friguet B (2006) Oxidized protein degradation and repair in ageing and oxidative stress. FEBS Lett 580:2910-2916

Frost BW (1972) Effects of size and concentration of food particles on the feeding behavior of the marine planktonic copepod Calanus pacificus. Limnol Oceanogr 17:805-815

Fryd M, Haslund OH, Wohlgemuth O (1991) Development, growth and egg production of the two copepod species Centropages hamatus and Centropages typicus in the laboratory. J Plankton Res 13:683-689

Gilbert JJ, Williamson CE (1983) Sexual dimorphism in zooplankton (Copepoda, Cladocera and Rotifera). Annu Rev Ecol Syst 14:1-33

Giron D, Casas J (2003) Mothers reduce egg provisioning with age. Ecol Lett 6:273-277

Hercus MJ, Hoffmann AA (2000) Maternal and grandmaternal age influence offspring fitness in Drosophila. Proc R Soc Lond B 267:2105-2110

- Hernebring M, Brolén G, Aguilaniu H, Semb H, Nyström T (2006) Elimination of damaged proteins during differentiation of embryonic stem cells. Proc Natl Acad Sci USA 103:7700-7705

Hirst AG, Kiørboe T (2002) Mortality of marine planktonic copepods: global rates and patterns. Mar Ecol Prog Ser 230:195-209

Ianora A, Miralto A, Poulet SA, Carotenuto Y and others (2004) Aldehyde suppression of copepod recruitment in blooms of a ubiquitous planktonic diatom. Nature 429: 403-407

Ikeda T (1977) Feeding rates of planktonic copepods from a tropical sea. J Exp Mar Biol Ecol 29:263-277

Jamieson CD, Santer B (2003) Maternal aging in the univoltine freshwater copepod Cyclops kolensis: variation in egg sizes, egg development times, and naupliar development times. Hydrobiologia 510:75-81

> Jónasdóttir S, Fields D, Pantoja S (1995) Copepod egg production in Long Island Sound, USA, as a function of the chemical composition of seston. Mar Ecol Prog Ser 119: $87-98$

- Kiørboe T (2006) Sex, sex-ratios, and the dynamics of pelagic copepod populations. Oecologia 148:40-50

Kiørboe T, Bagøien E (2005) Motility patterns and mate encounter rates in planktonic copepods. Limnol Oceanogr 50:1999-2007

> Kiørboe T, Mohlenberg F, Hamburger K (1985) Bioenergetics of the planktonic copepod Acartia tonsa: relation between 
feeding, egg production and respiration, and composition of specific dynamic action. Mar Ecol Prog Ser 26:85-97

Kirkwood TB (1999) Time of our lives: the science of human ageing. Oxford University Press, New York

Kirkwood TB, Austad SN (2000) Why do we age? Nature 408:233-238

Koski M, Breteler WK, Schogt N (1998) Effect of food quality on rate of growth and development of the pelagic copepod Pseudocalanus elongatus (Copepoda, Calanoida). Mar Ecol Prog Ser 170:169-187

Kregel KC, Zhang HJ (2007) An integrated view of oxidative stress in aging: basic mechanisms, functional effects, and pathological considerations. Am J Physiol Regul Integr Comp Physiol 292:18-36

Lance J (1965) Respiration and osmotic behaviour of the copepod Acartia tonsa in diluted sea water. Comp Biochem Physiol 14:155-165

Levine RL, Stadtman ER (2001) Oxidative modification of proteins during aging. Exp Gerontol 36:1495-1502

Matsuno T (2001) Aquatic animal carotenoids. Fish Sci 67: $771-783$

Mauchline J (1998) Introduction. In: Blaxter J, Southward A (eds) The biology of calanoid copepods. Adv Mar Biol 33: $1-13$

Medawar PB (1952) An unsolved problem of biology. HK Lewis, London

Monaghan P, Charmantier A, Nussey DH, Ricklefs RE (2008) The evolutionary ecology of senescence. Funct Ecol 22: 371-378

Morley JE (2001) Decreased food intake with aging. J Gerontol Ser A 56:81-88

Morley JE, Silver AJ (1988) Anorexia in the elderly. Neurobiol Aging 9:9-16

Mousseau TA, Dingle H (1991) Maternal effects in insect life histories. Annu Rev Entomol 36:511-534

Mousseau TA, Fox CW (1998) The adaptative significance of maternal effects. Trends Ecol Evol 13:403-407

Müller HG, Carey JR, Wu D, Liedo P, Vaupel JW (2001) Reproductive potential predicts longevity of female Mediterranean fruitflies. Proc Biol Sci 268:445-450

Müller-Navarra DC, Brett MT, Liston AM, Goldman CR (2000) A highly unsaturated fatty acid predicts carbon transfer between primary producers and consumers. Nature 403:74-77

Mullin MM, Sloan PR, Eppley RW (1966) Relationship between carbon content, cell volume and area in marine phytoplankton. Limnol Oceanogr 11:307-311

MZC2 (Marine Zooplankton Colloquium 2) (2001) Future marine zooplankton research-a perspective. Mar Ecol Prog Ser 222:297-308

Novoseltsev VN, Novoseltseva JA, Boyko SI, Yashin AI (2003a) What fecundity patterns indicate about aging and longevity: insights from Drosophila studies. J Gerontol Ser A 58:B484-B494

Novoseltsev VN, Novoseltseva JA, Yashin AI (2003b) What does a fly's individual fecundity pattern look like? The dynamics of resource allocation in reproduction and age-

Editorial responsibility: Matthias Seaman,

Oldendorf/Luhe, Germany ing. Mech Ageing Dev 124:605-617

Nussey DH, Coulson T, Festa-Bianchet M, Gaillard JM (2008) Measuring senescence in wild animal populations: towards a longitudinal approach. Funct Ecol 22:393-406

Ohman MD, Wood SN (1996) Mortality estimation for planktonic copepods: Pseudocalanus newmani in a temperate fjord. Limnol Oceanogr 41:126-135

Parrish KK, Wilson DF (1978) Fecundity studies on Acartia tonsa (Copepoda: Calanoida) in standardized culture. Mar Biol 46:65-81

Plourde S, Runge JA (1993) Reproduction of the planktonic copepod Calanus finmarchicus in the Lower St. Lawrence Estuary: relation to the cycle of phytoplankton production and evidence for a Calanus pump. Mar Ecol Prog Ser 102: $217-227$

> Ricklefs RE (2008) The evolution of senescence from a comparative perspective. Funct Ecol 22:379-392

Ryazanov AG, Nefsky BS (2002) Protein turnover plays a key role in aging. Mech Ageing Dev 123:207-213

- Seehuus SC, Norberg K, Gimsa U, Krekling T, Amdam GV (2006) Reproductive protein protects functionally sterile honey bee workers from oxidative stress. Proc Natl Acad Sci USA 103:962-967

Snell TW, Childress M (1987) Aging and loss of fertility in male and female Brachionus plicatilis (Rotifera). Invertebr Reprod Dev 12:103-110

Stearns SC, Ackermann M, Doebeli M, Kaiser M (2000) Experimental evolution of aging, growth and reproduction on fruitflies. Proc Natl Acad Sci USA 97:3309-3313

Tang KW, Freund CS, Schweitzer CL (2006) Occurrence of copepod carcasses in the lower Chesapeake Bay and their decomposition by ambient microbes. Estuar Coast Shelf Sci 68:499-508

Teegarden GJ (1999) Copepod grazing selection and particle discrimination on the basis of PSP toxin content. Mar Ecol Prog Ser 181:163-176

Tiselius P (1992) Behavior of Acartia tonsa in patchy food environments. Limnol Oceanogr 37:1640-1651

- Uye SI (1981) Fecundity studies of neritic calanoid copepods Acartia clausi Gisbrecht and A. steueri Smirnov: a simple empirical model of daily egg production. J Exp Mar Biol Ecol 50:255-271

> Volkman JK, Jeffrey SW, Nichols PD, Rogers GI, Garland CD (1989) Fatty acid composition of 10 species of microalgae used in mariculture. J Exp Mar Biol Ecol 128:219-240

Wichard T, Poulet SA, Halsband-Lenk C, Albaina A, Harris R, Liu D, Pohnert G (2005) Survey of the chemical defence potential of diatoms: screening of fifty species for $\alpha, \beta, \gamma$, $\delta$-unsaturated aldehydes. J Chem Ecol 31:949-958

Wikfors GH, Ohno M (2001) Impact of algal research in aquaculture. J Phycol 37:968-974

- Williams PD, Day T (2003) Antagonistic pleiotropy, mortality source interactions, and the evolutionary theory of senescence. Evolution 57:1478-1488

Yehuda S, Rabinovitz S, Carasso RL, Mostofsky DI (2002) The role of polyunsaturated fatty acids in restoring the aging neuronal membrane. Neurobiol Aging 23:843-853

Submitted: May 11, 2009; Accepted: December 16, 2009

Proofs received from author(s): February 15, 2010 